\title{
我々の行っている膝前十字勒帯再建術について
}

\begin{tabular}{|c|c|c|c|c|}
\hline 萩 & 原 & 博 & 嗣・中 & 家 \\
\hline 小 & 澤 & 慶 & 一・城 & 野 \\
\hline 真 & 鍋 & 尚 & 至 & \\
\hline
\end{tabular}

\section{Anterior Cruciate Ligament Reconstruction with Small Arthrotomy Incision}

\author{
Hiroshi Hagihara, Kazutoshi Nakaie, Keiichi Ozawa, \\ Osamu Jono and Takashi Manabe \\ Department of Orthopaedic Surgery, Sasebo Kyosai Hospital, Sasebo, Japan
}

The results of 27 anterior cruciate ligament (ACL) reconstructions were evaluated after a follow-up of 9 to 54 months. The central one third of the pateller tendon with proximal and distal bone plug was grafted through a small arthrotomy incision (open technique) to reconstruct the $\mathrm{ACL}$ in all cases.

The mean age of the patients was 22.7 years old.(renge, 15 to 43 years) The mean postoperative knee score of the Japanese Orthopaedic Association was 95.8 points. Relatively lower scores were seen in cases who already had degenerative osteoarthritis of the knee in the period of operation.

Testing with KT-1000 arthrometer was performed at $89 \mathrm{~N}$.

It revealed that the difference in the anterior laxity between the involved knee and contralateral knee improved from an average of $5.2 \mathrm{~mm}$ preoperatively to $1.1 \mathrm{~mm}$ postoperatively. All patients expressed satisfaction with the outcome.

Small arthrotomy incision showed no evidence of being a disadvantage to the results of the operation.

Key words : Anterior cruciate ligament（膝前十字勒帯), Autogenous bone-tendon-bone graft（自 家骨付膝蓋腱移植), Open technique（関節切開法）

はじめに

我々は膝前十字勒帯断裂に対して，自家骨付き膝蓋 腱を小関節切開下に interference fit screw で固定す る open-BTB 法を1994 年から行ってきた。 その術式 と成績について報告する.

対

象

手術後 9 ケ月以上経過した症例は 27 例で，手術時
年令は 15 歳から 43 歳, 平均 22.7 歳であった。この うち 21 例について直接検診による評価を行うことが できた．最終検診時までの術後経過期間は 4 年 6 ケ月 から 9 ケ月の間である. 性別は男性 9 例, 女性 18 例 である.

受傷原因はバスケットボール 6 例，バレーボール 6 例, ソフトボール 3 例, 柔道 2 例, その他のスポーツ 6 例，交通事故 3 例，転落 1 例であった.

合併損傷は, 内側半月板断裂 6 例, 外側半月板断裂 
4 例, 両側半月板断裂 2 例, 内側側副勒帯損傷 1 例, 外側側副勒帯損傷 1 例, 内外側半月板断裂に内側側副 勒帯断裂を合併したあの 1 例, 脛骨骨折 1 例であった. 前十字勒帯単独損傷は 11 例である.

受傷から手術までの期間は 1 週間から 8 年で, 平均 19 ケ月後である. 2 年以上経過した陳旧例が 6 例あ り, その年令は 20 才から 37 才, 平均 29.8 才と比較 的高かった.このうち 5 例では手術時既に, 膝単純レ 線上北大分類で stage I 及び II の変形性関節症変化が 認められた。

\section{手術法}

先ず関節鏡視を行い，必要に応じて鏡視下に半月板 等の処置を行う. 診断の為の関節鏡視のみを先に行い, 二次的に再建手術を行う事む多い.

膝蓋腱内縁部に約 $7 \mathrm{~cm}$ の皮膚切開を加え $1.5 \mathrm{~cm}$ の骨付きで膝蓋腱中 $1 / 3$ を採取. 骨にはエチボンド 糸 2 本づつを通して形を整え，両端を強く引っ張って 伸ばしておく.

膝蓋腱の $1 \mathrm{~cm}$ 内側に約 $4 \mathrm{~cm}$ の関節切開を加え, 直視下に ACL 残存組織を切除する.

大腿骨顆間窩の ACL 付着部後上縁から外上顆に向 けて, 両端の尖った直径 $2.4 \mathrm{~mm}$ 穴あきキルシュナー 鋼線を，穴が尾側にくるように刺入し，穴に糸をかけ

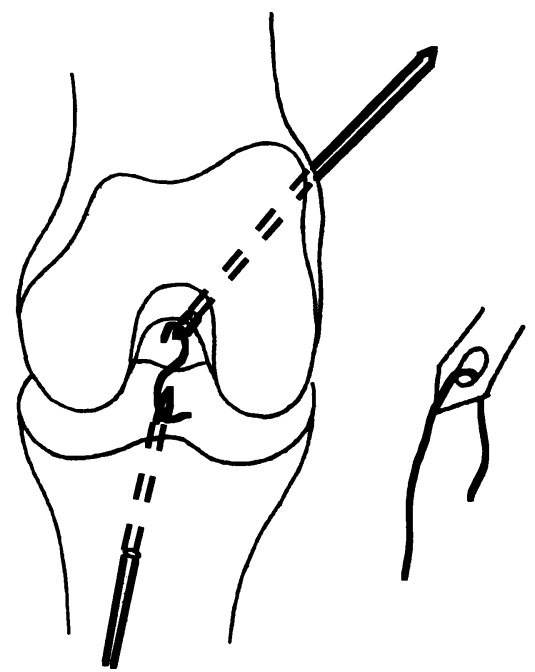

図 1 両尖穴開き $\mathrm{K}$ - wire を用いて糸を通し， isometricity を確認する.
て骨まで鋼線を引き込む，脛骨にも同様の鋼線を ACL 付着部に向けて通し, 系を脛骨前面に導き出し, isometricity の確認を行う（図 1 ）。大腿骨側の鋼線 をそのままドリルガイドとして直径 $10 \mathrm{~mm}$ の骨孔を inside out に穿つ. 脛骨にも骨孔を作製した後, 再び 大腿骨側の鋼線を関節内に戻して, BTB の骨片につ けた糸を骨孔内に引き込む. 骨片末端を開口部に一致 させて，スクリュー用のガイドワイヤを骨片に平行に 刺入し, 直径 $9 \mathrm{~mm}$ のクロサカスクリューで固定す る. 脛骨側も同様に, 最大緊張下にスクリュー固定を 行う. 関節鏡視に手間取らなければ, 手術は 1 ターニ ケット時間内に終わることができる.

術後は膝伸展制限は行わず，3 日目より装具をつけ て ROM 訓練を開始する.

\section{結果}

日本整形外科学会の膝勒帯損傷治療成績判定基準 (JOA Score) による評価では, 100 点満点が 21 例中 12 例, 90 点台が 5 例, 80 点台が 3 例, 70 点台 1 人で 平均 95.8 点と, 極めて良好であった. 80 点台の 3 人 中 2 人, 70 点台の 1 人はいずれも陳旧例であり, 坂 道や階段を降りる時の不安感と, 軽度の前方引き出し 症状が減点項目であった. giving way 症状は全くな かった，正坐は全例可能で，膝蓋部の腱採取の影響を 訴えるものはなかった.

本人の満足度は高かった。

KT-1000 による前方不安定性の評価では, $89 \mathrm{~N}$ 負 荷時の術前の健側と患側の差が $2.5 \sim 8.5 \mathrm{~mm}$, 平均 $5.2 \mathrm{~mm}$ であった. 術後は $1 \mathrm{~mm}$ 以下が 15 例, $3 \mathrm{~mm}$ 以上は 4 例, 平均 $1.1 \mathrm{~mm}$ であった. $3 \mathrm{~mm}$ 以上の 4 例中陳旧例が 2 例で, 術後経過 4 年以上の例が 3 例, 年令は 33 才, 34 才, 41 才, 43 才であった.

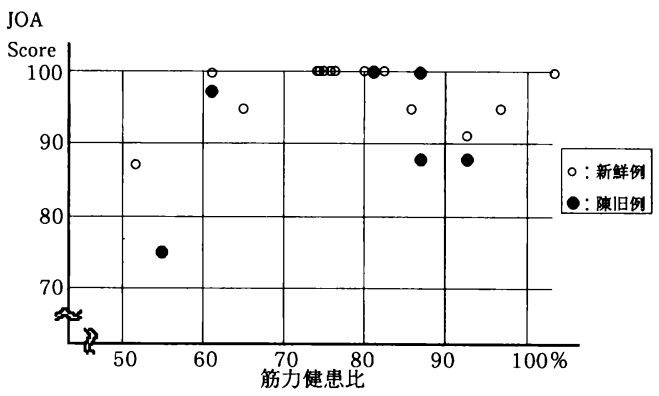

図 2 治療成績と大腿四頭筋筋力健患比（\%) 


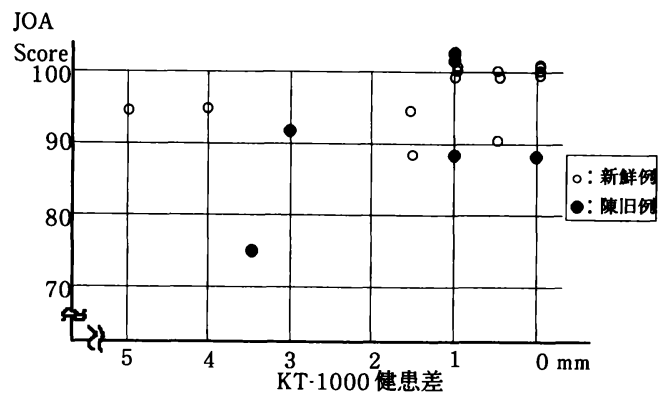

図 3 治療成績と KT-1000 評価（89N）

治療成績と大腿四頭筋の筋力との相関をみると, 健 側比 60\%以下の筋力低下例に成績不良が 2 例あるが， 筋力が弱くても成績の良いものああり, 一定の傾向と までは言えない（図 2).

同椂に治療成績と KT-1000 評価との相関について あ，健患差 $4 \mathrm{~mm}$ 以上の 2 例がいずれも JAO Score 95 点であり，一定の傾向はつかめなかった（図 3 ).

問題例として，直接検診ができなかった 1 例が，3 年後に他地域の病院で再手術を受けていた。手術時 16 歳の女性で, 術後 2 ケ月目に独断で柔道の試合に 出場し, その後も柔道を続けていた症例である.

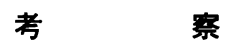

今日, 自家 BTB による膝前十字勒帯再建術はゴー ルデンスタンダードと言われ, 安定した成績が報告さ れている1．我々の成績あ良好であった．陳旧性で手 術時に変形性膝関節症の所見のあった例に成績不良例 が多いのは言わば当然の結果であり, 今後の経過観察 が必要である. 術後経過の長い症例で KT - 1000 評価 の不良例が目立つことの理由には，経時的にゆるんだ 事と, 初期の症例であった為に手術手技上の問題であっ たことの両方が考えられる. しかし KT-1000 評価と JOA Score とは相関関係を示しておらず, end point がしっかりしている限り, 軽度の前方不安定性は成績 不良に直ちに結びっくあのではないように思われる. 一方で又，KT-1000 評価には正確さや再現性の上で 信頼性に欠けるという指適もあり ${ }^{2)}$ ，少なくとも臨床 評価に関する限り，KT-1000 評価を重要視すること
は避けた方がよいようである.

最近の膝前十字勒帯再建術の学会発表などでは，鏡 視下手術によるものがほとんどで，「手術侵襲を軽減 する為」という文言があたかあ枕詞のように述べられ ている. 果して常にそうであろうか. 我々の関節小切 開による方法では, 皮席切開は BTB 採取時の 1 ケ所 のみであり, 術後リハビリテーションの遅れを含め, 臨床成績に影響を及ぼすような侵襲が加わっていると は考えられない，直視下では大腿骨側の骨孔作製位置 の確認がし難いとの指摘があるが, 膝を深い屈曲位と してライトを水平に近く当てることにより，この部位 を確認する事には困難を感じていない．

一方鏡視下手術にあ，手技的に難しく，手術時間が 長くなりがちであるなどの欠点がある. ターニケット 時間が長くなれば, 筋肉の阻血性の障害などの機能低 下の原因となる.

又，ある程度頻繁に手術を行う機会がなければ習熟 するのは困難であることあ考えておく必要がある.

アメリカでは Raabや Gameron など多くの論者が 両者の優劣について述べているが，成績に明らかな差 があるとしたものは見当らな( ${ }^{334) . ~}$

$$
\text { 結語 }
$$

膝前十字勒帯再建術全体の侵襲の中では, 関節小切 開の影響は小さなあのであって, 術者は自分自身の経 験や条件にあわせて, こだわりなく手術方法を選択す るべきである.

\section{参 考 文 献}

1) Frank, C. B. and Jackson, D. B. : The science of reconstruction of the anterior cruciate ligatent. J. Bone Joint Syrg., 79-A : 1556-1573, 1997.

2) Forster, I. W. et al. : Is the KT- 1000 knee ligament arthrometer reliable?. J. Bone Joint Syrg., 71-B : 843$847,1989$.

3) Raab, D. J. et al. : Comparison of arthroscopic and open reconstruction of the anterior cruciate ligament. Am. J. Sports Med., 21 : 680-684, 1993.

4) Cameron, S. E. et al. : A prospective, randamized comparizon of open vs arthroscopically assisted ACL reconstruction. Orthopedics, $18: 249-252,1995$. 